\title{
Strategi Guru Baca Tulis Qur'an dalam Mengatasi Kesulitan Membaca Al-Qur'an pada Siswa Kelas VIII di MTs Al Fatimiyah Karawang
}

\author{
Wihelis fitriani ${ }^{1}$ Abu Bakar Umar ${ }^{2}$ Ilham Fahmi ${ }^{3}$ \\ 1 (Pendidikan Agama Islam, Universitas Singaperbangsa Karawang, Indonesia). \\ 2 (Pendidikan Agama Islam, Universitas Singaperbangsa Karawang Indonesia). \\ ${ }^{3}$ (Pendidikan Agama Islam, Universitas Singaperbangsa Karawang, Indonesia). \\ * Corresponding Author. E-mail: wihelisfitriani@gmail.com
}

\begin{tabular}{|l|l|l|}
\hline Receive: 13/05/2021 & Accepted: 23/08/2021 & Published: 01/10/2021
\end{tabular}

\begin{abstract}
ABSTRAK
Kesulitan membaca Al-Qur'an merupakan suatu hambatan kegiatan pembelajaran di dalam kelas, hal ini yang melatarbelakangi penulis untuk mengkaji permasalahan tersebut. Kemudian, penelitian ini bertujuan untuk mengetahui kesulitan yang dialami siswa dalam membaca AlQur'an, kemudian faktor pendukung dan penghambat bagi guru dalam mengatasinya, selanjutnya strategi yang digunakan guru Baca Tulis Al-Qur'an dalam mengatasi kesulitan membaca Al-Qur'an. Metode yang di gunakan dalam penelitian ini yaitu metode penelitian kualitatif, jenis penelitian ini bersifat deskriptif dan pendekatan penelitian menggunakan pendektan fenomologi. Kemudian subjek pada penelitian ini yaitu siswa kelas VIII MTs Al Fatimiyah Karawang dan sampel penelitian berjumlah 20 orang siswa non mukim. Adapun instrument yang digunakan yaitu teknik pengumpulan data dengan cara wawancara, observasi dan dokumentasi. Hasil penelitian ini menunjukan bahwa strategi yang digunakan guru dapat mengatasi kesulitan siswa dalam membaca Al-Qur'an diantaranya mengenalkan huruf hijaiyah terlebih dahulu, mengadakan private dan menciptakan pembelajaran yang lebih menarik. Berdasarkan pengumpulan data yang di peroleh di lapangan, diketahui bahwa strategi yang dilakukan tersebut mampu meningkatkan hasil belajar membaca Al-Qur'an.
\end{abstract}

Kata Kunci: Strateg guru, Kesulitan membaca Al-Qur'an, Al-qur'an hadist.

\begin{abstract}
The difficulty of reading the Qur'an is an obstacle to learning activities in the classroom, this is the background for the author to examine these problems. Then, this study aims to determine the difficulties experienced by students in reading the Qur'an, then the supporting and inhibiting faktors for teachers in overcoming them, then the strategies used by the Reading and Writing Al-Qur'an teachers in overcoming difficulties in reading the Qur'an. The method used in this study is a qualitative research method, this type of research is descriptive and the research approach uses a phenomology approach. Then the subjects in this study were students of class VIII MTs Al Fatimiyah Karawang and the research sample amounted to 20 non-mukim students. The instrument used is data collection techniques by means of interviews, observation and documentation. The results of this study indicate that the strategies used by the teacher can overcome students' difficulties in reading the Qur'an including introducing hijaiyah letters first, holding private and creating more interesting learning. Based on data collection obtained in the field, it is known that the strategy carried out is able to improve learning outcomes to read the Qur'an
\end{abstract}

Keywords: Strategy, difficulty reading the Al-Qur'an, Al-Qur'an hadith 


\section{Pendahuluan}

Undang-Undang Nomor 20 Tahun 2003 Tentang Sistem Pendidikan Nasional menjelaskan bahwa guru merupakan pendidik profesional dengan tugas utama mendidik, mengajar, membimbing, mengarahkan, melatih, menilai dan mengevaluasi pesesrta didik pada pada pendidikan anak usia dini jalur pendidikan formal, pendidikan dasar, dan pendidikan menengah. Guru merupakan orang yang memiliki profesionalitas dalam tenaga kependidikan Islam yang bertanggung jawab memberikan pengetahuan, bimbingan, serta bantuan kepada peseta didik dalam mengembangkan kedewasaannya baik dalam ranah kognitif, afektif maupun psikomotorik sesuai dengan ajaran agama Islam yaitu menaati Allah SWT dan Rasul-Nya serta menjauhi larangan-Nya (Muhammad \& Aladdiin, n.d, 2019:152). Adapun peran guru yang dimaksud disini adalah berkaitan dengan peran guru dalam proses pembelajaran membaca Al-Qur'an. Guru merupakan faktor penentu yang sangat dominan dalam pendidikan pada umumnya, karena guru memegang peranan dalam proses pembelajaran, dimana proses pembelajaran merupakan inti dari proses pendidikan secara keseluruhan.

Mendidik merupakan kompetensi dasar yang mendukung kemampuan seorang guru dalam menjalankan tugasnya, sehingga tinggi tendahnya motivasi seorang guru akan terlihat dari upaya yang dilakukan dalam mengembangkan dan meningkatkan mutu

Artinya: "Dan sungguh, kami telah mudahkan Al-Qur'an sebagai pelajaran, maka adakah orang yang mengambil pelajaran."(AlQur'an dan Terjemah Departemen Agama Tahun 2004 -QS. Al-Qomar ayat 22).

proses pendidikan (Rusman, 2014:93). Kesulitan membaca merupakan suatu hambatan bagi siswa dalam mencapai tujuan belajar, karena membaca merupakan kompenen utama yang harus dicapai oleh siswa dalam proses pembelajaran. Kesulitan membaca sering juga disebut dengan disleksia yaitu kesulitan yang berhubungan dengan kata atau simbol-simbol. Istilah disleksia banyak digunakan dalam dunia kedokteran dan dikaitkan dengan adanya gangguan fungsi neurofisiologi (Mulyadi, 2016:154). Oleh karena itu, siswa yang mengalami kesulitan tersebut tidak terlepas keterkaitannya dengan kesulitan Bahasa, karena kompenen tersebut merupakan pokok utama dari system komuikasi yang terintegerasi. Penelitian ini bertujuan untuk mengetahui kesulitan apa saja yang dialami siswa dalam membaca Al-Qur'an, kemudian apa saja faktor pendukung dan penghambat bagi guru BTQ dalam mengatasinya, lalu startegi apa yang digunakan guru Baca Tulis Qur'an dalam mengatasi kesulitan membaca Al-Qur'an pada siswa kelas VIII di MTs Al Fatimiyah Karawang.

Berdasarkan hal tersebut kesulitan dalam membaca Al-Qur'an merupakan sebuah tantangan bagi guru dalam proses pembelajaran, karena setiap kegiatan pembelajaran akan muncul hambatanhambatan yang dialami siswa dalam belajar. Kegiatan pembelajaran tidak akan selamanya berjalan lancar, karena dalam kegiatan belajar mengajar kita akan menemukan permasalahan yang terjadi khususnya di dalam kelas. Berdasarkan hal ini, permasalahan yang dialami siswa yaitu kesulitan membaca Al-Qur'an, karena belajar membaca Al-Qur'an tidak semudah pembelajaran pada umumnya. Guru sebagai tenaga pendidik harus menyiapkan strategi atau upaya untuk mengatasi permasalahan tersebut, disamping itu guru juga harus mengetahui apa saja faktor pendukung serta penghambat dalam mengatasi hal tersebut. Adapun ayat Al-Qur'an yang berkaitan dengan hal tersebut diantaranya dijelakan dalam QS.Al-Qomar ayat 22 yang berbunyi:

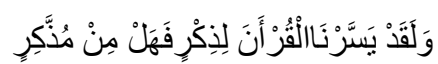

Berdasarkan ayat Di atas dijelaskan bahwa telah dimudahkan bagi seseorang yang akan mempelajari Al-Qur'an, kemudian adakah seseorang yang akan mempelajarinya. Adapun kaitannya dengan judul yang peneliti angkat yaitu ketika seseorang bersungguh-sungguh dalam 
belajar membaca Al-Qur'an, maka akan dimudahkan baginya untuk mempelajari AlQur'an. Kemudian ayat tersebut diperkuat oleh QS.Al-Insyirah ayat 5 yang berbunyi:

$$
\text { فَإِنَّ مَعَ الْعُسرِيُسْرًا }
$$

$\begin{array}{llr}\text { Artinya: } & \text { "Sebab sesungguhnya } & \text { setelah } \\ & \text { kesulitan itu } & \text { ada } \\ \text { kemudahan"(Al-Qur'an dan } & \text { Terjemah Departemen Agama - } \\ & \text { QS.Al- Insyirah ayat 5). }\end{array}$

Selain itu ada bebetapa faktor yang menjadi penyebab kesulitan siswa dalam membaca Al-Qur'an diantaranya faktor biologis yang berhubungan dengan riwayat keluarga yang pernah mengalaminya, kemudian yang kedua kehamilan yang bermasalah lalu yang terakhir adalah masalah kesehatan yang cukup relevan. Adapun penyebab kesulitan yang kedua diantaranya faktor kognitif yaitu pola artikulasi Bahasa dan siswa yang memiliki kekurangan kesadaran untuk mempelajari tentang bunyi-bunyi Bahasa. Selain kedua faktor tersebut, faktor perilaku menjadi salah satu penyebab kesulitan membaca diantaranya siswa mempunyai permasalahan dalam hubungan sosial, stress dan gangguan motoric.

Berdasarkan hal tersebut, ada beberapa cara untuk mengatasi kesulitan dalam membaca Al-Qur'an diantaranya melakukan pendekatan kepada individu, kemudian memahami kendala atau kesulitan yang dialami, lalu memberi solusi untuk mengatasi kesulitan yang dialami tersebut. Selain itu adapula faktor pendukung dan penghambat bagi guru dalam mengatasi kesulitan membaca Al-Qur'an tersebut diantaranya faktor penghambat yang berasal dari siswa, contohnya siswa yang mempunyai kelemahan dalam menghafal huruf hijaiyah. Kemudian faktor dari sekolah yaitu kurangnya jam pelajaran secara tatap muka, adapula serta kurangnya interaksi antara guru dan siswa.

Menurut Kemp menjelaskan bahwa strategi pembelajaran merupakan kegiatan pembelajaran yang harus dikerjakan oleh guru dan siswa agar tujuan pembelajaran dapat dicapai secara efektif dan efisien (Sanjaya, 2016:126). Dalam mengatasi kesulitan membaca Al-Qur'an tersebut guru harus mempersiapkan strategi yang khusus, dan adapun strategi guru Baca Tulis Qur'an dalam mengatasi kesulitan membaca AlQur'an diantaranya yaitu fokus mengenalkan huruf-huruf hijaiyah terlebih dahulu kemudian mengadakan private dan membuat pembelajaran lebih menarik, contohnya seperti mengadakan game huruf hijaiyah, game tajwid, tebak surat dan lain sebagainya.

\section{Metode}

Penelitian ini menggunakan metode penelitian kualitatif yaitu metode penelitian yang menggunakan pendekatan naturalistic untuk mencari dan menemukan pemahaman tentang fenomena dalam suatu latar yang berkonteks khusus (Lexy, 2017:6). Jenis penelitian ini bersifat deskriptif yang bertujuan untuk menggambarkan secara utuh dan mendalam realita social yang terjadi di lapangan. Penelitian ini menggunakan pendekatan fenomologi yaitu penelitian yang mencoba menggali dan menemukan pengalaman hidup manusia terhadap dirinya. Adapun instrument yang digunakan untuk memperoleh data yang diperlukan yaitu dengan teknik pengumpulan data. Kemudian yang menjadi subjek dalam penelitian ini yaitu siswa kelas VIII di MTs Al Fatimiyah Karawang.

Peneliti akan melakukan observasi mengenai strategi guru Baca Tulis Qur'an dalam mengatasi kesulitan membaca AlQur'an pada siswa kelas VIII di MTs Al Fatimiyah Karawang. Kemudian observasi yang dilakukan dengan cara mewawancarai pihak yang bersangkutan yaitu guru Baca Tulis Qur'an dan siswa kelas VIII di MTs Al Fatimiyah, baik secara langsung ataupun tidak langsung. Berdasarkan hal tersebut, penelitian ini menggunakan teknik analisis data yaitu proses mencari dan menyusun secara sistematis data yang diperoleh dari hasil wawancara, catatan lapangan dan dokumentasi, dengan cara mengorganisasikan data kedalam kategori (Sari, 2020:29). Kemudian teknik analisa data yang bersifat induktif, dimana analisa data dilakukan berdasarkan data yang diperoleh, kemudian dari data tersebut dikembangkan menjadi hipotesis. 
Adapun tahapan-tahapan yang dilakukan dalam penelitian ini, yang pertama ialah koleksi data, adapun menurut koleksi data merupakan suatu langkah yang di nilai strategis dalam melaksanakan penelitian, karena memiliki tujuan utama dalam memperoleh data (Sugiono, 2016:193). Berdasarkan teori yang dikemukakan di atas, tahap pertama yang dilakukan dalam penelitian ini yaitu mengoleksi atau mengumpulkan data yang diperoleh di lapangan. Kemudian tahap yang kedua yaitu reduksi data atau merangkum, memilih hal pokok, memfokuskan pada hal-hal yang penting kemudian mencari tema dan polanya. Selanjutnya tahap yang ketiga adalah menyajikan data yang telah dirangkum ke dalam bentuk uraian dan tahap yang terakhir yaitu verifikasi data atau menyimpulkan data dari keseluruhan, karena data pertama yang diperoleh masih bersifat sementara kemudian akan berubah jika tidak ditemukan bukti yang kuatdan mendukung pada tahap pengumpulan data berikutnya.

\section{Hasil dan Pembahasan}

Kompetensi yang dimiliki siswa tidaklah sama, ada sebagian siswa yang cepat tanggap dalam menangkap materi yang disampaikan oleh guru, adapula siswa yang lambat dalam menangkap pelajaran ketika di dalam kelas. Berdasarkan hal tersebut, guru harus lebih pandai mengatur strategi pembelajaran di dalam kelas, bertujuan agar siswa merasa senang dan nyaman ketika pembelajaran berlangusng. Adapun permasalahan yang peneliti kaji yaitu mengenai kesulitan membaca Al-Qur'an pada siswa kelas VIII di MTs Al Fatimiyah Karawang.

Bersumber pada data yang diperoleh dari hasil wawancara dengan guru Baca Tulis Qur'an dan siswa yang mengalami kesulitan tersebut bahwa bentuk kesulitan yang dialami peserta didik diantaranya yaitu kesulitan melafalkan huruf hijaiyah sesuai makhrojnya, huruf idghom mutamatsilain, mutajaisain dan mutaqoribain. Selain itu kesulitan dalam mengaplikasikan kaidah ilmu tajwid kedalam bacaan Al-Qur'an serta sulit membedakan panjang pendek suatu bacaan. Keterangan tersebut diperkuat oleh teori terdahulu yang menyatakan bahwa ketika membaca Al-Qur'an, setiap huruf yang di buyikan harus sesuai dengan makhrojnya karena kesalahan dalam pengucapan huruf atau makhroj dapat menyebabkan perbedaan makna dan kesalahan pada bacaan yang telah dibaca (Sari, 2020:).

Selain itu, adapula faktor pendukung untuk membantu guru Baca Tulis Qur'an dalam mengatasi kesulitan membaca AlQur'an pada siswa kelas VIII di MTs Al Fatimiyah diantaranya kerjasama yang baik antara guru dan orang tua. Adapula beberapa faktor yang menjadi penghambat guru dalam mengatasi hal tersebut yang pertama kurangnya jam pelajaran tatap muka sehingga dapat menghambat proses pembelajaran, kemudian kurangnya keaktifan orang tua dalam membimbing anaknya di rumah dan yang terakhir kurangnya interaksi antara guru dan siswa. Hal tersebut di uraikan sesuai dengan data dan fakta yang diperoleh di lapangan dengan melakukan wawancara secara langsung.

Berdasarkan hasil wawancara dengan pihak yang bersangkutan strategi yang dilakukan oleh guru Baca Tulis Qur'an dalam mengatasi siswa yang mengalami kesulitan membaca Al-Qur'an diantaranya mengenalkan huruf hijiyah terlebih dahulu, karena huruf hijaiyah merupakan dasar pembelajaran dalam membaca Al-Qur'an, kemudian mengadakan private atau melakukan bimbingan secara khusus dan yang terakhir yaitu membuat kegiatan pembelajaran lebih menarik seperti mengadakan game huruf hijaiyah, game tajwid, tebak surat dan lain-lain sehingga siswa merasa senang serta nyaman ketika melaksanakan kegiatan belajar membaca AlQur'an. Dengan demikian, dapat disimpulkan bahwa strategi yang dilakukan guru Baca Tulis Qur'an dalam mengatasi kesulitan membaca Al-Qur'an mampu memberi perubahan sehingga siswa lebih mudah belajar membaca Al-Qur'an.

\section{Simpulan}

Berdasarkan hasil penelitian di lapangan dengan teknik pengumpulan data, maka diperoleh hasil, kesulitan yang dialami siswa dalam membaca Al-Qur'an sangat beragam, 
ada yang mengalami kesulitan melafalkan huruf sesuai makhrojnya, kemudian menerapkan kaidah ilmu tajwid dan kesulitan dalam membedakan panjang pendek suatu huruf. Adapun faktor pendukung yang membantu guru Baca Tulis Qur'an dalam mengatasi kesulitan tersebut diantaranya kerjasama yang baik antara guru dan wali murid. Sedangkan faktor penghambat yang dialami guru dalam kesulitan tersebut diantaranya kurangnya jam pelajaran tatap muka, kemudian kurangnya keaktifan orang tua dalam membimbing anaknya di rumah, serta kurangnya interaksi antara guru dan siswa. Selanjutnya, strategi guru Baca Tulis Qur'an dalam mengatasi kesulitan tersebut diantanya mengenalkan huruf hijaiyah terlebih dahulu, kemudian mengadakan private dan terakhir membuat pembelajaran yang menarik, seperti mengadakan games huruf hijaiyah, tajwid dan tebak surat. Bersumber pada penjelasan di atas, terdapat pula data yang menghasilkan temuan bahwa peningkatan belajar membaca Al-Qur'an setelah menggunakan strategi tersebut, adanya peningkatan dalam membaca $\mathrm{Al}$ -

\section{Profil Penulis}

Wihelis fitriani. Karawang, 23 Januari 1999. Mahasiswa S1 Fakultas Agama Islam, Prodi Pendidikan Agama Islam UniversitasSingaperbangsa Karawang. Jl. HS. Ronggo Waluyo, Paseurjaya, Kec. Teluk Jambe Timur Kabupaten Karawang, Jawa Barat 41361
Qur'an karena strategi yang digunakan cukup menarik dan tidak membuat bosan siswa dalam melaksanakan kegiatan pembelajaran.

\section{Daftar Pustaka}

Moeloeng, Lexy J. (2017). Metode Penelitian Kualitatif. PT.Remaja Rosdakarya.

Mulyadi. (2016). Kesulitan Membaca..

Muhammad, H., \& Aladdiin, F. Peran Materi Pendidikan Agama Islam di Sekolah dalam Membentuk Karakter Kebangsaan.

Sari. (2020). Peran Guru Al-Qur'an Hadist dalam Mengatasi Kesulitan Membaca AlQur'an di Madrasah Tsanawiyah Satu Atap (MTs-SA) Darun Nasyi'in Bumi Jawa Bataghari Nuban.

Rusman. (2014). Model-Model Pembelajaran. PT. RajaGrapindo.

Sanjaya. (2016). Strategi Pembelajaran. Prenadamedia Group.

Sugiono. (2016). penelitian kualitatif. 